\title{
Arbuscular Mycorrhizal Fungal Diversity in Sugarcane Rhizosphere in Relation with Soil Properties
}

\author{
Promita DATTA, Mohan KULKARNI \\ University of Pune, Department of Chemistry, Division of Biochemistry, Pune-411007, Maharashtra, India; drmvkulkarni@gmail.com
}

\begin{abstract}
Arbuscular mycorrhizal (AM) species diversity and their root colonization patterns may vary in a plant species as influenced by soil environmental and biological factors. In the present study, sugarcane rhizospheric soils were collected from 41 main sugarcane producing tehsil places belonging to 10 districts from Maharashtra, India. Rhizospheric soil samples and roots were analyzed for spore density, relative abundance and frequency of AM spores at genus as well as at species level, extent of AM colonization in roots and various soil chemical properties. Soil sample from Jalgaon district possessed maximum spore density and AM root colonization. Genus Glomus exhibited highest relative abundance with maximum frequency of $32.55 \%$. Species wise, Glomus fasciculatum possessed highest relative abundance and maximum frequency was observed in case of Glomus fasciculatum, Glomus intraradices, Glomus mosseae and Glomus versiforme. Maximum similarity of AM spores was recorded between Satara and Sangli districts which may be because of almost similar soil $\mathrm{pH}$ profile. Data obtained after cluster analysis represented the close relationship between spore density, AM root colonization and soil $\mathrm{Cu}, \mathrm{Zn}$ and $\mathrm{Fe}$ concentrations. A statistically significant positive correlation was also found when AM spore density and root colonization was compared with soil $\mathrm{Cu}, \mathrm{Zn}$ and Fe contents. This kind of data can be used to predict type of AM fungi to be used as bioinoculant in particular region.
\end{abstract}

Keywords: arbuscular mycorrhizal fungi, frequency, mycorrhizal root colonization, relative abundance, soil chemical properties

\section{Introduction}

Arbuscular mycorrhizal fungi (AMF) are considered as obligate biotrophic symbionts and are associated with the fine roots of over $80 \%$ terrestrial plant species (Smith and Read, 1997). In this plant-fungus association, fungus depends upon host plant for nutrition and reproduction and in return provides phosphate and essential mineral nutrients from soil to the host plant. AMF belongs to phylum Glomeromycota is characterized as formation of Arum type root colonization pattern whereas, Gigasporaceae form Arum type or intermediate types of AM with Paris type hyphal coil structure (Dickson et al., 2007; Smith et al., 2004).

The main function of AM fungi is of phosphorus transportation. Extra-radical mycelium of AM fungi easily access P from soil and deliver to root cortical cells as polyphosphate which finally translocate to host plant after solubilization and it is estimated that external hyphae deliver up to $80 \%$ of $\mathrm{P}$ requirement of the plant (Matamoros et al., 1999). Other than P translocation, AM fungi provide protection to host plant roots from soil-borne pathogenic attack, they improve tolerance of plants to several abiotic stresses, including drought and saline stress condition, by producing plant growth hormones, maintain stability of soil aggregation, increase resistance to diseases etc (Evelin et al., 2009). In addition, mycorrhizal association also enhances nitrogen uptake as well as utilization of several micro nutrients. AM fungi successfully colonize with a wide range of plant species and are considered as non-host specific (Evelin et al., 2009). Population of AM fungi is highly influenced by several environmental factors including climatic conditions, soil physico-chemical status, age and variety of host plant and several agricultural practices etc. Additionally, different species of AM fungi differ in their tolerance to adverse physical and chemical condition in soil (Kumar and Ghose, 2008). It is already reported that, AMF is naturally occur in saline environment and their spore density is improved as saline stress stimulates sporulation (Sengupta and Chaudhuri, 1990; Tressner and Hayes, 1971). Mc Millen et al. (1998) reported that, salt stress inhibited AM spore germination as well as hyphal growth. It was observed that, plants growing in severe wet places seem to be non mycorrhizal but became mycorrhizal when water table is lowered. Likewise, rice in flooded soil is non mycorrhizal and became colonized when grown in non flooded soil. Also, winter wheat which usually is planted in autumn in temperate climates may not become mycorrhizal until spring (Asai, 1934). Moreover, plant species also vary in their symbiotic responsiveness to AM fungi with respect to plant growth, reproduction, abiotic stress, disease resistance etc (Danesh et al., 2006).

Among a wide range of host species, plant belonging to Poaceae family is considered as one of the host of AM fungi (Powell, 1984). Sugarcane is one of the most important cash crop belonging to this family and West- 
ern Maharashtra is considered as the traditionally sugarcane growing areas in India and accounts for $60 \%$ of the national contribution. Ahmednagar, Satara and Kolhapur districts are recognized as sugarcane belt in Western Maharashtra. In Maharashtra, crop rotation in sugarcane cultivation is not used in regular practices. Crop rotation, with legumes planting has some positive effect on sugarcane productivity by improving soil fertility; reduce erosion etc (Ambrosano et al., 2010). Sugarcane production

Tab. 1. Study site with their geographical coordinates of various tehsil places belonging to surveyed 10 districts of Maharashtra

\begin{tabular}{|c|c|c|}
\hline District & Tehsil & Coordinates \\
\hline \multirow{2}{*}{ Dhule } & Sindkheda & $21^{\circ} 18^{\prime} 30^{\prime \prime} \mathrm{N}$ and $74^{\circ} 43^{\prime} 18^{\prime \prime} \mathrm{E}$ \\
\hline & Shirpur & $21^{\circ} 22^{\prime} 12^{\prime \prime} \mathrm{N}$ and $74^{\circ} 57^{\prime} 10^{\prime \prime} \mathrm{E}$ \\
\hline \multirow{3}{*}{ Aurangabad } & Aurangabad & $19^{\circ} 54^{\prime} 2^{\prime \prime} \mathrm{N}$ and $75^{\circ} 21^{\prime} 34^{\prime \prime} \mathrm{E}$ \\
\hline & Phulambri & $20^{\circ} 7^{\prime} 34^{\prime \prime} \mathrm{N}$ and $75^{\circ} 24^{\prime} 46^{\prime \prime} \mathrm{E}$ \\
\hline & Khuldabad & $20^{\circ} 3^{\prime} 23^{\prime \prime} \mathrm{N}$ and $75^{\circ} 12^{\prime} 33^{\prime \prime} \mathrm{E}$ \\
\hline \multirow{3}{*}{ Beed } & Beed & $18^{\circ} 59^{\prime} 13^{\prime \prime} \mathrm{N}$ and $75^{\circ} 49^{\prime} 5^{\prime \prime} \mathrm{E}$ \\
\hline & Wadwani & $18^{\circ} 59^{\prime} 7^{\prime \prime} \mathrm{N}$ and $76^{\circ} 3^{\prime} 10^{\prime \prime} \mathrm{E}$ \\
\hline & Parli & $18^{\circ} 51^{\prime} 1^{\prime \prime} \mathrm{N}$ and $76^{\circ} 7^{\prime} 20^{\prime \prime} \mathrm{E}$ \\
\hline \multirow{8}{*}{ Ahmednagar } & Ahmadnagar & $19^{\circ} 69^{\prime \prime} \mathrm{N}$ and $74^{\circ} 43^{\prime} 34^{\prime \prime} \mathrm{E}$ \\
\hline & Parner & $19^{\circ} 0^{\prime} 29^{\prime \prime} \mathrm{N}$ and $74^{\circ} 27^{\prime} 21^{\prime \prime} \mathrm{E}$ \\
\hline & Sangamner & $19^{\circ} 34^{\prime} 25^{\prime \prime} \mathrm{N}$ and $74^{\circ} 14^{\prime} 22^{\prime \prime} \mathrm{E}$ \\
\hline & Kopargaon & $19^{\circ} 53^{\prime} 38^{\prime \prime} \mathrm{N}$ and $74^{\circ} 29^{\prime} 43^{\prime \prime} \mathrm{E}$ \\
\hline & Shrirampur & $19^{\circ} 7^{\prime} 10^{\prime \prime} \mathrm{N}$ and $74^{\circ} 39^{\prime} 37^{\prime \prime} \mathrm{E}$ \\
\hline & Rahuri & $19^{\circ} 23^{\prime} 4^{\prime \prime} \mathrm{N}$ and $74^{\circ} 39^{\prime} 12^{\prime \prime} \mathrm{E}$ \\
\hline & Karjat & $18^{\circ} 33^{\prime} 44^{\prime \prime} \mathrm{N}$ and $75^{\circ} 00^{\prime} 49^{\prime \prime} \mathrm{E}$ \\
\hline & Jamkhed & $18^{\circ} 43^{\prime} 18^{\prime \prime} \mathrm{N}$ and $75^{\circ} 19^{\prime} 26^{\prime \prime} \mathrm{E}$ \\
\hline \multirow{6}{*}{ Pune } & Pune & $18^{\circ} 32^{\prime} 6^{\prime \prime} \mathrm{N}$ and $73^{\circ} 52^{\prime} 20^{\prime \prime} \mathrm{E}$ \\
\hline & Junnar & $19^{\circ} 12^{\prime} 50^{\prime \prime} \mathrm{N}$ and $73^{\circ} 53^{\prime} 23^{\prime \prime} \mathrm{E}$ \\
\hline & Mulshi & $18^{\circ} 30^{\prime} 4^{\prime \prime} \mathrm{N}$ and $73^{\circ} 30^{\prime} 50^{\prime \prime} \mathrm{E}$ \\
\hline & Sirur & $18^{\circ} 50^{\prime} 7^{\prime \prime} \mathrm{N}$ and $74^{\circ} 23^{\prime} 13^{\prime \prime} \mathrm{E}$ \\
\hline & Baramati & $18^{\circ} 9^{\prime} 6^{\prime \prime} \mathrm{N}$ and $74^{\circ} 35^{\prime} 43^{\prime \prime} \mathrm{E}$ \\
\hline & Daund & $18^{\circ} 28^{\prime} 40^{\prime \prime} \mathrm{N}$ and $74^{\circ} 36^{\prime} 13^{\prime \prime} \mathrm{E}$ \\
\hline \multirow{6}{*}{ Satara } & Satara & $17^{\circ} 41^{\prime} 10^{\prime \prime} \mathrm{N}$ and $73^{\circ} 59^{\prime} 25^{\prime \prime} \mathrm{E}$ \\
\hline & Koregaon & $17^{\circ} 43^{\prime} 28^{\prime \prime} \mathrm{N}$ and $74^{\circ} 10^{\prime} 11^{\prime \prime} \mathrm{E}$ \\
\hline & Khatar & $17^{\circ} 47^{\prime} 4^{\prime \prime} \mathrm{N}$ and $74^{\circ} 11^{\prime} 48^{\prime \prime} \mathrm{E}$ \\
\hline & Patan & $17^{\circ} 36^{\prime} 46^{\prime \prime} \mathrm{N}$ and $73^{\circ} 9^{\prime} 18^{\prime \prime} \mathrm{E}$ \\
\hline & Karad & $17^{\circ} 43^{\prime} 6^{\prime \prime} \mathrm{N}$ and $74^{\circ} 10^{\prime} 19^{\prime \prime} \mathrm{E}$ \\
\hline & Phaltan & $17^{\circ} 59^{\prime} 19^{\prime \prime} \mathrm{N}$ and $74^{\circ} 2629^{\prime \prime} \mathrm{E}$ \\
\hline \multirow{6}{*}{ Sangli } & Miraj & $16^{\circ} 50^{\prime} 22^{\prime \prime} \mathrm{N}$ and $74^{\circ} 38^{\prime} 54^{\prime \prime} \mathrm{E}$ \\
\hline & Kavathe & $17^{\circ} 0^{\prime} 32^{\prime \prime} \mathrm{N}$ and $74^{\circ} 51^{\prime} 55^{\prime \prime} \mathrm{E}$ \\
\hline & Tasgaon & $17^{\circ} 2 ' 29^{\prime \prime} \mathrm{N}$ and $74^{\circ} 3633^{\prime \prime} \mathrm{E}$ \\
\hline & Islampur & $17^{\circ} 354^{\prime \prime} \mathrm{N}$ and $74^{\circ} 1644^{\prime \prime} \mathrm{E}$ \\
\hline & Khanapur & $17^{\circ} 1629^{\prime \prime} \mathrm{N}$ and $74^{\circ} 43^{\prime} 49^{\prime \prime} \mathrm{E}$ \\
\hline & Atpadi & $17^{\circ} 25^{\prime} 11^{\prime \prime} \mathrm{N}$ and $74^{\circ} 57^{\prime} 48^{\prime \prime} \mathrm{E}$ \\
\hline Jalgaon & Bhusawal & $21^{\circ} 3^{\prime} 15^{\prime \prime} \mathrm{N}$ and $75^{\circ} 4621^{\prime \prime} \mathrm{E}$ \\
\hline \multirow{5}{*}{ Kolhapur } & Kanvir & $21^{\circ} 23^{\prime} 5^{\prime \prime} \mathrm{N}$ and $75^{\circ} 49^{\prime} 29^{\prime \prime} \mathrm{E}$ \\
\hline & Panhala & $16^{\circ} 49^{\prime} 24^{\prime \prime} \mathrm{N}$ and $74^{\circ} 74^{\prime} 44^{\prime \prime} \mathrm{E}$ \\
\hline & Shirol & $16^{\circ} 44^{\prime \prime} 2^{\prime \prime} \mathrm{N}$ and $74^{\circ} 36^{\prime} 48^{\prime \prime} \mathrm{E}$ \\
\hline & Bhudargad & $15^{\circ} 49^{\prime} 22^{\prime \prime} \mathrm{N}$ and $74^{\circ} 51^{\prime} 13^{\prime \prime} \mathrm{E}$ \\
\hline & Chandgad & $15^{\circ} 56^{\prime} 12^{\prime \prime} \mathrm{N}$ and $74^{\circ} 12^{\prime \prime} 7^{\prime \prime} \mathrm{E}$ \\
\hline Osmanabad & Osmanabad & $18^{\circ} 11^{\prime} 49^{\prime \prime} \mathrm{N}$ and $76^{\circ} 3^{\prime} 31^{\prime \prime} \mathrm{E}$ \\
\hline
\end{tabular}

is mostly groundwater dependent as it requires high water availability at various growth stages (Shrivastava et al., 2011). Since ground water table is getting reduced, new technique should be incorporated to sustain sugarcane productivity and it includes use of AM fungi as bioinoculant to tolerate drought stress, use of genetically modified sugarcane variety which requires less water for growth etc. Another major factor affecting sugarcane production is red rot disease caused by Colletotrichum falcatum. But, the severity of this disease is reduced by AM inoculation (Nasim et al., 2008). Though several factors influence the population of AM fungi in rhizospheric soil but, species composition, quantification, identification of AM fungus in cultivated soils of different locations is necessary as well as impact of several soil factors on their colonization and symbiotic efficiency is also required. As there is no report, with regards to mycorrhizal status and diversity of AM fungi in sugarcane rhizospheric soil from sugarcane growing regions in Maharashtra and hence, the present study was aimed to investigate AM spore distribution in sugarcane rhizospheric soil and their root colonization profiling in relation to several soil properties.

\section{Materials and methods}

\section{Study site and soil sampling}

In Maharashtra, sugarcane crop is mainly cultivated in Western part and Ahmednagar, Satara and Kolhapur districts are known to be major sugarcane growing regions. In addition, sugarcane is also cultivated in some parts of Sangli, Pune, Osmanabad, Aurangabad, Beed, Dhule and Jalgaon. During August 2009 to December 2010, a total of 41 sugarcane rhizospheric soil samples were collected from various tehsils of 10 districts of Maharashtra with geographical, environmental and soil variations (Tab. 1). Soil samples from various surveyed places were collected only once and not seasonally.

Rhizospheric soil including sugarcane roots and stump were collected from 10 different fields belonging to each tehsil. For this purpose, 8-10 sub-samples (each of $1 \mathrm{~kg}$ soil including roots) were collected to a depth of $5-20 \mathrm{~cm}$ from various sampling points (the distance between two sampling points was of about 5-8 meters) from each field. These sub-samples were brought to laboratory in sealed polythene bags and then thoroughly mixed. Finally, a composite sample was prepared by thorough mixing of samples from all fields belonging to a particular tehsil. Some representative roots from each composite sample were separated from adhering soil followed by proper rinsing under tap water and fixed in formalin : acetic acid : alcohol until AM root colonization was estimated. Rhizospheric soil samples were air dried in shade at room temperature and one-third part of each sample was used for determination of soil chemical properties, for development of trap culture and for spore counting. 
68

Extraction, counting and identification of AM spores

One-third part of each collected soil sample was used for AM spore extraction using the method described by Gerdemann and Nicolson (1963). Spore extraction was done in two triplicates for individual soil sample and in each case $50 \mathrm{~g}$ of sample was mixed with $500 \mathrm{ml}$ water followed by thorough stirring and then the suspension was sieved through a series of sieves $(37 \mu-500 \mu)$. Each sieving was collected and was subjected to sucrose centrifugation (Daniels and Skipper, 1982). Spores were collected on grid-lined filter paper and then counted using trinocular compound microscope. During counting, sporocarp and spores in cluster were considered as one spore and spore density was expressed in terms of number of spores per $100 \mathrm{~g}$ of dry soil sample.

Relative abundance (RA) (\%) and frequency (F) (\%) of AM spore was calculated by the following formulae (Kumar and Ghose, 2008):

RA $(\%)=$ (number of AM spores of a genus or a species/total number of spores) X 100

$F(\%)=$ (number of samples in which genus or species of AM fungi was observed/total number of samples) $\mathrm{X}$ 100.

Another one-third part of each collected soil sample was used to establish trap culture in $10 \mathrm{~L}$ plastic pot. At this stage, trap culture was found necessary to obtain healthy, viable spores with prominent structural appearance which are important for identification of AM fungi at species level. Trap was developed by mixing field collected soil sample (including root pieces) and autoclaved river sand (autoclaved at $121^{\circ} \mathrm{C}$, for three times at an interval of 4 days) $(1: 1, \mathrm{v} / \mathrm{v})$, with maize as a host plant. Plants were allowed to grow for 6 months under green house conditions (temperature $30 / 20^{\circ} \mathrm{C}$ day $/$ night, a relative humidity of 60-65\% and at a photon flux intensity of around 280-350 $\mu \mathrm{mol} / \mathrm{m}^{2} / \mathrm{s}$ ). At the end of growing cycle, AM spore counting was done using above mentioned method and trap culture was designated as positive, when AM spore counts (per $100 \mathrm{~g}$ dry soil) were increased as compared with field collected sample and detection of new fresh spores which were undetected in field collected samples. Fresh, healthy, morphologically similar spores (around 25-30 for each type) were extracted from trap culture followed by separation and fixed on glass slide in PVLG and PVLG with Melzer's reagent. Identification of each spore type was done on the basis of color, shape, size, surface ornamentation, spore wall structure and type of hyphal attachment as per the description provided in the database (www.amfphylogeny.com) and as per the standard key features given in manual (Schenck and Perez, 1990). Identification of $\mathrm{AM}$ spores was done after trap culturing as propagation of field collected AM species sometimes require controlled environment.

\section{Estimation of AM root colonization (\%)}

To estimate AM root colonization, root samples were removed from fixative and washed with deionized water followed by cutting into $1 \mathrm{~cm}$ pieces. The root pieces were thoroughly mixed and a sub-sample $(0.5 \mathrm{~g})$ was cleared in hot $\mathrm{KOH}$ solution $\left(10 \% \mathrm{w} / \mathrm{v}\right.$, at $\left.90^{\circ} \mathrm{C}\right)$ for $1 \mathrm{~h}$. Cooled root samples were washed with deionized water and placed in $\mathrm{HCl}(10 \%, \mathrm{v} / \mathrm{v})$ for $3 \mathrm{~min}$ and stained with trypan blue $\left(0.05 \%, \mathrm{w} / \mathrm{v}\right.$ ) for $15 \mathrm{~min}$ at $90^{\circ} \mathrm{C}$ (Phillips and Hayman, 1970). Percentage of AM colonization in sugarcane root samples was estimated by gridline intersect method (Giovannetti and Mosse, 1980).

\section{Soil chemical characteristics}

Soil $\mathrm{pH}$ and $\mathrm{EC}$ (at $25^{\circ} \mathrm{C}$ ) were analyzed from suspension of soil:water (1:5) and organic carbon (OC) was measured according to the method of Walkley and Black (1934). Concentration of $\mathrm{Na}$, available $\mathrm{P}$ (Olsen P), K, $\mathrm{Ca}, \mathrm{Mg}, \mathrm{Cu}, \mathrm{Zn}, \mathrm{Fe}$ in soil samples were estimated according to the standard methods (Jackson, 1973; Kalra and Maynard, 1991).

\section{Statistical analysis}

Values for spore number and root colonization (\%) were subjected to $\log _{e}(x+1)$ transformation and arcsine square root transformation respectively for normalization of the data (St. John and Koske, 1988; Zar, 1984). Pearson's correlation coefficient was calculated between spore number, root length colonization and soil properties. Statistical significant difference was set at $\mathrm{P}<0.01$ level. Agglomerative hierarchical cluster analysis was done using average linkage within groups and the result of complex multivariate relationship among the variables was expressed as dendrogram. SPSS software version 9.0 was used for the statistical analysis.

\section{Results}

In the present investigation, individual dataset of spore density, root length colonization as well as soil chemical properties of each tehsil place are not illustrated rather, district wise mean values of spore density, root length colonization and soil chemical properties were calculated and mentioned. As certain species of AM fungi do not turn up in trap culture as well as some individual spore types in different trap cultures did not multiply at the same rate and hence to avoid ambiguity, spore density, frequency and relative abundance of AM spores were calculated from field collected soil samples.

\section{$A M$ spore density and Percentage of $A M$ root colonization}

Fig. 1 present district wise dataset of mean values of AM spore density and percent AM root colonization observed in sugarcane plant roots. Among the ten surveyed districts, rhizospheric soil from Jalgaon district had maximum spore density (395 spores / $100 \mathrm{~g}$ soil) and Dhule had the least mean spore density (137 spores / $100 \mathrm{~g}$ soil). The spore density of the three major sugarcane growing districts namely, Ahmednagar, Satara and Kolhapur ranged between 239-324 spores/100 g soil. Spore density from several districts was found in increasing order of Dhule> 
Sangli $>$ Beed $>$ Ahmadnagar $>$ Pune $>$ Osmanabad $>$ Sat ara $>$ Kolhapur $>$ Aurangabad $>$ Jalgaon (Fig. 1). The average AM root colonization was observed within a range of 27.75-57.17\% among ten districts. Highest AM root colonization was observed in root samples collected from Jalgaon district $(57.17 \%)$ and least colonization was recorded in root samples collected from Dhule district (27.75\%) (Fig. 1).

\section{Frequency and relative abundance of $A M$ spores}

Totally five AM genera namely, Glomus, Gigaspora, Acaulospora, Scutellospora and Sclerocystis including 32 species were identified from forty one soil samples after positive trap culturing. After species level identification, it was observed that, 15 species were belonging to genus Glomus, 4 species each of Gigaspora and Acaulospora, 6 species were of Scutellospora and 3 species of Sclerocystis.

Among the five genera of AM fungi observed, relative abundance of AM spores occurred in the Glomus (75.39\%) followed by Acaulospora (8.62\%) and Scutellospora $(8.47 \%)$. Lowest relative abundance of AM spores was observed for genus Gigaspora (5.83\%) and Sclerocystis (1.69\%). Genus wise maximum frequency of spores was observed for Glomus followed by Scutellospora, Acaulospora, Sclerocystis and Gigaspora and ranged from $34.78 \%$ to 7.09\% (Fig. 2).

When species wise relative abundance and frequency were calculated, it was observed that, Glomus fascicula-

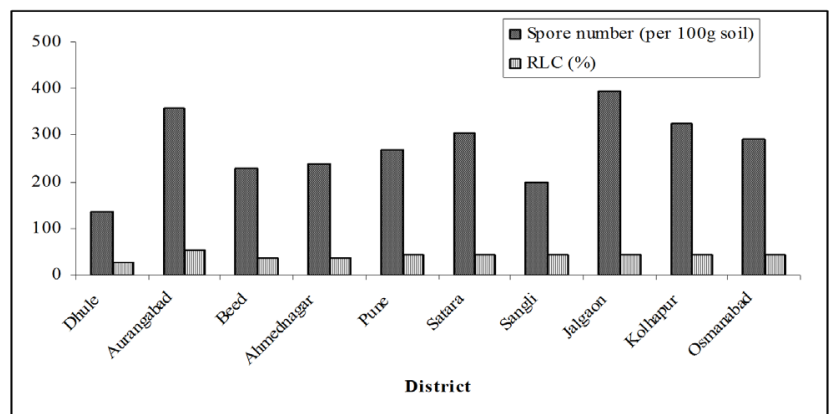

Fig. 1. Mean spore density (per $100 \mathrm{~g}$ dry soil) and AM root length colonization (RLC) (\%) observed district wise. Mean values were calculated from the data obtained in all tehsil places belonging to particular district tum, had highest RA value of $17.44 \%$ followed by Glomus intraradices and Glomus mosseae (14.16\% and $9.67 \%$ respectively); whereas, Scutellospora nigra had the least RA value $(0.25 \%)$ (Fig. 3). Species wise highest frequency was observed for four AM species such as Glomus fasciculatum, Glomus intraradices, Glomus mosseae and Glomus versiforme (each of 3.13\%) and the lowest frequency occurred for Scutellospora nigra (0.76\%) and Scutellospora heterogama $(0.69 \%)$.

In the present study, several AM spore types observed in each tehsil place are presented in Tab. 2. It was observed that, four species of genus Glomus were present in all the soil samples collected from various districts. Whereas, other species of genus Glomus and the species belonging to genus Gigaspora, Acaulospora, Scutellospora and Sclerocystis were found in soils of some tehsil places only. Also, out of forty one soil samples from various tehsil places, Scutellospora nigra was observed at nine locations and Scutellospora heterogama at ten locations amongst the surveyed areas (Tab. 2).

\section{Chemical properties of soil}

District wise mean values of several soil chemical properties were obtained (Tab. 3). Among the ten districts selected for study, soil samples from Dhule, Beed, Ahmednagar, Pune and Jalgaon were of alkaline type while the remaining five districts Aurangabad, Satara, Sangli, Kolhapur and Osmanabad had slightly acidic soil (Tab. 3).

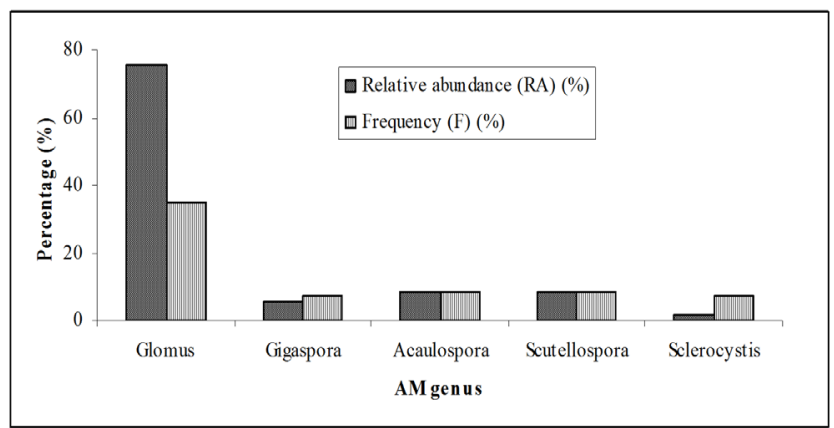

Fig. 2. Relative abundance (RA) (\%) and frequency (F) (\%) of AM spores identified at genus level from the soil samples. Mean values were calculated from the data obtained in all tehsil places belonging to the particular district

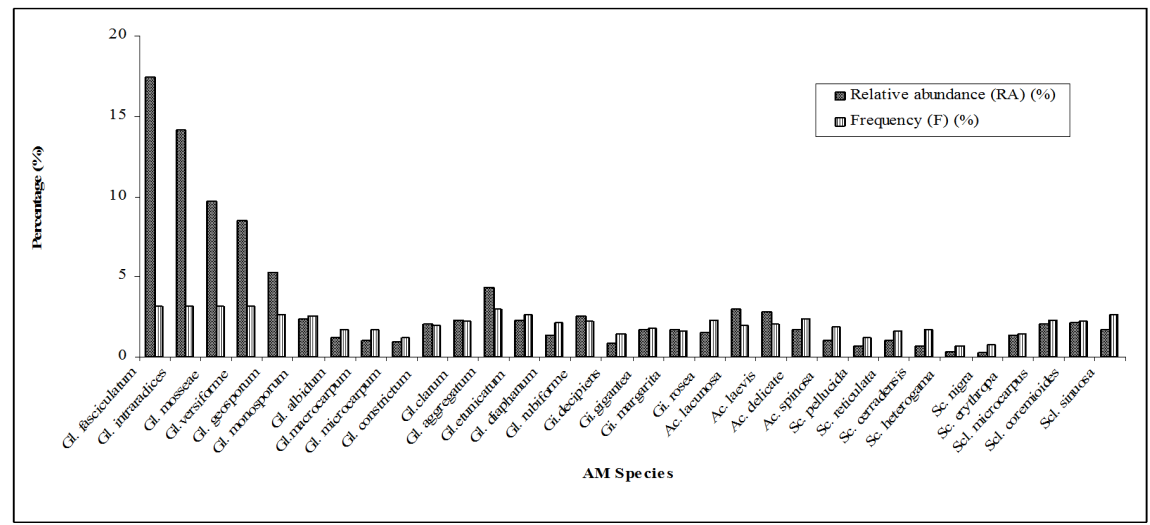

Fig. 3. Relative abundance (RA) (\%) and frequency (F) (\%) of AM spores identified at species level from the soil samples. Mean values were calculated from the data obtained in all tehsil places belonging to particular district. Note: Gl-Glomus, Gi-Gigaspora, Ac-Acaulospora, Sc-Scutellospora, Sc-Sclerocystis 
Tab. 2. Distribution (presence or absence) of each AM spore type observed in surveyed tehsil places

\begin{tabular}{|c|c|c|c|c|c|c|c|c|c|c|c|c|c|c|c|c|c|c|c|c|c|c|c|c|c|c|c|c|c|c|c|c|}
\hline Site & Gf & Gi & $\mathrm{Gm}$ & $\mathrm{Gv}$ & $\mathrm{Gg}$ & Gmo & $\mathrm{Ga}$ & Gma & Gmi & $\mathrm{Gc}$ & Gcl & Gag & $\mathrm{Ge}$ & $\mathrm{Gd}$ & Gr & Gid & Gig & Gim & Gir & $\mathrm{Acl}$ & Acla & Acd & Acs & Scp & Scr & Scc & Sch & Scn & Sce & Sclm & Sclc & Sds \\
\hline Ds & + & + & + & + & - & - & + & - & - & + & - & + & - & - & + & - & + & + & - & + & + & + & - & + & + & - & - & - & - & - & + & + \\
\hline Dsh & + & + & + & + & + & - & - & + & - & - & - & + & + & + & + & - & + & + & + & - & - & + & + & - & + & + & - & - & - & - & + & - \\
\hline $\mathrm{Aa}$ & + & + & + & + & + & - & - & - & - & + & + & + & + & + & + & - & - & - & + & + & + & + & + & + & - & - & - & + & - & + & + & - \\
\hline Ap & + & + & + & + & + & + & - & - & - & + & + & + & + & + & + & - & - & + & - & + & + & + & + & - & - & + & - & + & - & + & + & + \\
\hline $\mathrm{Ak}$ & + & + & + & + & + & + & - & - & - & + & + & + & + & + & + & - & - & - & + & + & + & + & + & + & - & + & - & + & - & + & + & + \\
\hline $\mathrm{Bb}$ & + & + & + & + & & + & & & & + & & + & & & + & & + & + & & + & + & + & & + & + & & & & & & + & + \\
\hline $\mathrm{Bw}$ & + & + & + & + & + & + & - & - & + & + & + & + & + & + & + & - & - & - & - & + & + & + & - & - & + & + & - & - & - & + & + & + \\
\hline Bp & + & + & + & + & + & + & + & & & & & + & + & & + & + & & + & & + & + & + & & + & + & & & & + & + & + & + \\
\hline Aah & + & + & + & + & + & - & - & - & - & + & + & + & + & - & + & - & - & - & + & + & + & + & + & + & + & - & - & - & + & + & + & + \\
\hline Apa & + & + & + & + & + & + & & + & + & + & + & + & + & & + & + & & & + & + & + & + & + & + & + & & & & + & + & & + \\
\hline As & + & + & + & + & - & - & - & + & - & + & - & + & + & + & + & - & + & + & + & - & - & + & + & - & + & + & - & - & - & - & + & + \\
\hline Ako & + & + & + & + & + & + & + & - & - & + & + & + & - & - & + & - & - & - & + & + & - & - & + & + & + & - & - & - & + & + & - & + \\
\hline Ash & + & + & + & + & + & + & - & - & . & + & + & + & + & + & + & - & + & + & + & + & + & - & - & - & + & + & - & - & - & + & + & + \\
\hline $\mathrm{Ar}$ & + & + & + & + & + & - & - & + & - & - & + & + & + & + & + & + & + & + & + & - & + & + & + & - & - & + & - & - & - & - & + & + \\
\hline Aka & + & + & + & + & - & + & - & + & - & - & + & + & + & - & + & - & + & + & + & - & - & - & + & - & - & + & - & - & - & + & + & + \\
\hline $\mathrm{Aj}_{\mathrm{j}}$ & + & + & + & + & & & & + & & & + & + & + & & + & & + & + & + & & & & + & & & + & & & + & + & + & + \\
\hline $\mathrm{Pp}$ & + & + & + & + & + & + & + & - & - & + & + & + & - & - & + & - & - & - & + & - & - & + & + & - & + & + & - & - & - & - & + & + \\
\hline $\mathrm{Pj}$ & + & + & + & + & + & + & + & & & + & + & + & - & - & + & & - & - & + & + & & - & + & + & + & - & & & + & + & & + \\
\hline $\mathrm{Pm}$ & + & + & + & + & + & - & - & + & - & + & + & + & + & - & + & + & - & - & + & + & + & + & - & - & - & + & - & - & + & + & - & + \\
\hline Ps & + & + & + & + & + & + & - & + & + & & & + & + & + & + & & + & & + & - & & + & + & - & + & + & & & & + & + & + \\
\hline $\mathrm{Pb}$ & + & + & + & + & + & + & + & - & - & + & - & - & + & + & - & + & + & - & + & + & - & + & + & - & - & + & - & - & - & - & + & + \\
\hline $\mathrm{Pd}$ & + & + & + & + & + & + & & - & & & & + & + & + & + & & & + & + & + & + & + & & & + & & & & + & + & + & + \\
\hline Ss & + & + & + & + & + & + & + & - & - & - & - & + & + & + & + & - & - & - & + & + & + & + & + & - & - & + & - & - & + & + & + & + \\
\hline Sk & + & + & + & + & + & + & + & & & & + & + & + & + & + & & + & & + & + & + & + & + & - & & + & & + & + & + & + & + \\
\hline Skh & + & + & + & + & - & - & + & + & + & - & - & + & + & + & + & + & - & - & + & + & + & - & - & + & - & - & + & - & - & + & + & + \\
\hline $\mathrm{Sp}_{\mathrm{p}}$ & + & + & + & + & + & + & & + & & & & + & + & + & + & + & & & + & + & + & + & & & & & & + & + & + & + & + \\
\hline Ska & + & + & + & + & + & + & - & + & - & - & - & + & + & + & + & + & - & - & + & + & + & + & - & - & - & - & - & + & + & + & + & + \\
\hline Sph & + & + & + & + & + & + & & - & + & + & + & + & - & + & + & - & + & - & + & - & - & + & + & + & + & + & - & + & - & + & + & + \\
\hline $\mathrm{Sm}$ & + & + & + & + & + & + & + & + & + & + & + & + & + & + & - & + & + & + & + & + & + & + & + & - & - & + & - & + & + & + & - & + \\
\hline Skav & + & + & + & + & + & + & + & + & + & + & + & + & + & + & + & + & + & & + & + & + & + & + & & + & + & + & & - & + & & \\
\hline St & + & + & + & + & + & + & + & + & - & + & + & + & + & - & - & - & - & - & - & - & - & + & + & - & - & + & + & + & + & - & - & + \\
\hline $\mathrm{Si}$ & + & + & + & + & + & + & + & & + & & + & + & + & + & & + & & & + & & & + & + & + & & & & & & & + & \\
\hline Skha & + & + & + & + & + & + & + & - & - & - & + & - & + & + & . & - & + & - & - & - & - & + & + & - & - & - & + & + & + & - & + & + \\
\hline $\mathrm{Sa}$ & + & + & + & + & + & + & + & + & + & + & + & + & + & + & & + & + & + & + & + & + & + & & - & & & & & + & + & + & \\
\hline $\mathrm{Jb}$ & + & + & + & + & + & + & + & + & + & + & + & + & + & + & - & + & + & + & - & - & + & + & + & + & + & + & - & - & - & . & - & + \\
\hline $\mathrm{Kk}$ & + & + & + & + & + & + & + & + & + & + & + & + & + & + & & + & + & + & & + & + & & + & & & & + & & & + & & \\
\hline Kp & + & + & + & + & + & + & + & + & + & + & + & + & + & + & + & + & + & + & + & + & + & + & - & + & + & - & + & - & + & + & - & + \\
\hline Ks & + & + & + & + & + & + & + & + & + & + & + & + & + & + & - & + & + & + & - & + & + & - & - & + & - & - & + & - & - & + & + & + \\
\hline $\mathrm{Kb}$ & + & + & + & + & + & + & + & + & + & + & + & + & + & + & - & + & + & + & - & - & + & - & - & + & + & - & + & - & - & + & - & + \\
\hline $\mathrm{Kc}$ & + & + & + & + & + & + & + & + & + & + & + & + & + & + & & + & + & + & + & & + & & & - & + & + & & & + & + & + & + \\
\hline Oo & + & + & + & + & + & + & + & + & + & + & + & + & + & + & - & + & + & + & + & - & - & + & - & - & + & + & + & 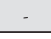 & + & + & 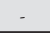 & + \\
\hline
\end{tabular}

Note-Gf-Glomus fasciculatum, Gi-Glomus intraradices, Gm-Glomus mosseae, Gv-Glomus versiforme, Gg-Glomus gesporum, Gmo-Glomus monosporum, Ga-Glomus albidum, Gma-Glomus macrocarpum, Gmi-Glomus microcarpum, Gc-Glomus constrictum, Gcl-Glomus clarum, Gag-Glomus aggregatum, Ge-Glomus etunicatum, Gd-Glomus diaphanum, Gr-Glomus rubiforme, Gid-Gigaspora decipiens, Gig-Gigaspora gigantea, Gim-Gigaspora margarita, Gir-Gigaspora rosea, Acl-Acaulospora lacunosa, Acla-Acaulospora laevis, Acd-Acaulospora delicata,

Acs-Acaulospora spinosa, Scp-Scutellospora pellucida, Scr-Scutellospora reticulata, Scc-Scutellospora cerradensis, Sch-Scutellospora heterogama, Scn-Scutellospora nigra, Sce-Scutellospora erytbropa, Sclm-Sclerocystis microcarpus, Sclc-Sclerocystis coremioides, Scls-Sclerocystis sinuosa. Ds-Sindkheda (Dhule), Dsh-Shirpur (Dhule), Aa-Aurangabad, Ap-Phulambri (Aurangabad), Ak-Khuldabad (Aurangabad), Bb-Beed, Bw-Wadwani (Beed), Bp-Parli (Beed), Aah-Ahmadnagar, Apa-Parner (Ahmadnagar), As-Sangamner (Ahmadnagar), Ako-Kopargaon (Ahmadna
Ash-Shrirampur (Ahmadnagar), Ar-Rahuri (Ahmadnagar), Aka-Karjat (Ahmadnagar), Ai-Jamkhed (Ahmadnagar), Pp-Pune, Pi-Junnar (Pune), Pm-Mulshi (Pune), Ps-Shirur (Pune), Pb-Baramati (Pune), Pd-Daund (Pune), Ss-Satara, Sk-Koregaon (Satara), Skh-Khatar (Satara),

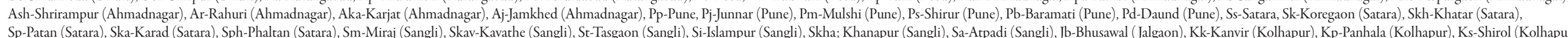

Sp-Patan (Satara), Ska-Karad (Satara), Sph-Phaltan (Satara), Sm-Miraj (Sangli), Skav-Kavathe (Sang
Kb-Bhudargad, Kc-Chandgad (Kolhapur), Oo-Osmanabad. '+'"means Presence, "'- means Absence 
Highest value of organic carbon and EC were observed in Dhule district, followed by Sangli and the lowest count was recorded in Jalgaon district. Data from Tab. 3 also indicated that, with increase in soil EC value, there was an increase in available $\mathrm{Na}, \mathrm{Ca}$ and $\mathrm{Mg}$ concentrations in most of the districts.

Soils from Dhule district possessed highest concentration of available $\mathrm{P}, \mathrm{Na}, \mathrm{Ca}, \mathrm{Mg}$ and $\mathrm{K}$. But, this soil contained least amount of $\mathrm{Zn}, \mathrm{Cu}$ and $\mathrm{Fe}$. Concentrations of minor elements such as $\mathrm{Zn}, \mathrm{Cu}$ and Fe were found superior in soils from Osmanabad and Aurangabad districts.

\section{Jaccard index}

Data of Jaccard similarity index is presented in Tab. 4 , which gives the idea of presence of similar type of AM fungi between two sugarcane growing regions. The highest similarities of AM spores were found in Satara/Sangli and Ahmadnagar/Sangli and it may be due to similarity in $\mathrm{pH}$ of soil from these districts (Tab. 3).
Statistical correlation analysis and cluster analysis

Following Pearson's correlation analysis, it was observed that, spore density can be positively correlated with extent of root colonization and so, the percentage of AM root colonization was increased with increasing spore density. AM spore density showed a significantly positive correlation with concentrations of $\mathrm{Zn}, \mathrm{Cu}$ and $\mathrm{Fe}$ whereas, a significant $(\mathrm{P}<0.01)$ negative correlation was observed when spore density was compared with other soil properties such as soil $\mathrm{pH}, \mathrm{EC}$, organic carbon, available $\mathrm{P}, \mathrm{Na}$, $\mathrm{Ca}, \mathrm{Mg}$ and $\mathrm{K}$ concentrations (Tab. 5). A significant positive correlation existed between AM root colonization and concentrations of $\mathrm{Zn}, \mathrm{Cu}$ and Fe. Except $\mathrm{pH}$ of soil samples, the remaining soil properties were negatively correlated $(\mathrm{P}<0.01)$ with AM root colonization (Tab. 5$)$.

The dendrogram obtained after agglomerative hierarchical cluster analysis using average linkage within group, showed the close relationship among the variables namely spore density, AM root colonization, concentrations of $\mathrm{Cu}, \mathrm{Zn}, \mathrm{Fe}$, soil $\mathrm{pH}$ and available P. But, relationship be-

Tab. 3. District wise mean soil chemical properties. Mean value of each parameter was calculated from the data obtained from different tehsil places respective to particular district

\begin{tabular}{|c|c|c|c|c|c|c|c|c|c|c|c|}
\hline Site & $\mathrm{pH}$ & $\begin{array}{c}\mathrm{EC} \\
(\mathrm{d} S / \mathrm{m})\end{array}$ & $\mathrm{OC}(\%)$ & $\begin{array}{c}\mathrm{P} \\
(\mathrm{kg} / \mathrm{ac})\end{array}$ & $\begin{array}{c}\mathrm{Na} \\
(\mathrm{meq} / \\
100 \mathrm{~g})\end{array}$ & $\begin{array}{c}\mathrm{K} \\
(\mathrm{kg} / \mathrm{ac})\end{array}$ & $\begin{array}{c}\mathrm{Ca} \\
(\mathrm{meq} / \\
100 \mathrm{~g})\end{array}$ & $\begin{array}{c}\mathrm{Mg} \\
\text { (meq/ } \\
100 \mathrm{~g})\end{array}$ & $\begin{array}{c}\mathrm{Zn} \\
(\mathrm{ppm})\end{array}$ & $\begin{array}{c}\mathrm{Cu} \\
(\mathrm{ppm})\end{array}$ & $\begin{array}{c}\mathrm{Fe} \\
(\mathrm{ppm})\end{array}$ \\
\hline Dhule & $7.91 \pm 0.4$ & $1.86 \pm 0.2$ & $2.74 \pm 0.0$ & $22.49 \pm 0.1$ & $29.9 \pm 0.9$ & $2.7 \pm 0.1$ & $9.55 \pm 0.2$ & $6.37 \pm 0.6$ & $0.73 \pm 0.1$ & $0.66 \pm 0.1$ & $18.25 \pm 5$ \\
\hline Aurangabad & $6.43 \pm 0.1$ & $0.28 \pm 0.0$ & $0.92 \pm 0.1$ & $7.79 \pm 0.1$ & $1.22 \pm 0.2$ & $0.11 \pm 0.0$ & $3.19 \pm 0.3$ & $2.06 \pm 0.2$ & $16.21 \pm 0.3$ & $13.24 \pm 0.2$ & $86.44 \pm 4$ \\
\hline Beed & $8.3 \pm 0.4$ & $0.86 \pm 0.1$ & $1.48 \pm 0.0$ & $11.84 \pm 0.1$ & $18.22 \pm 0.4$ & & $5.27 \pm 0.2$ & $3.59 \pm 0.3$ & $1.64 \pm 0.1$ & $4.48 \pm 0.3$ & \\
\hline Ahmednagar & $7.23 \pm 0.2$ & & $1.69 \pm 0.0$ & $16.62 \pm 0.1$ & $20.03 \pm 0.1$ & $1.99 \pm 0.0$ & $6.04 \pm 0.1$ & $3.98 \pm 0.1$ & $3.62 \pm 0.1$ & & \\
\hline Pune & $8.3 \pm 0.1$ & $0.91 \pm 0.1$ & $1.3 \pm 0.0$ & $10.95 \pm 0.2$ & $14.89 \pm 0.2$ & $1.35 \pm 0.0$ & $5.03 \pm 0.3$ & $3.1 \pm 0.1$ & $9.14 \pm 0.2$ & $6.55 \pm 0.1$ & $51.28 \pm 3$ \\
\hline Satara & $6.9 \pm 0.1$ & $0.44 \pm 0.0$ & $0.72 \pm 0.0$ & $9.67 \pm 0.1$ & $4.04 \pm 0.1$ & $0.37 \pm 0.0$ & $3.56 \pm 0.2$ & $2.4 \pm 0.2$ & $8.48 \pm 0.2$ & $5.91 \pm 0.3$ & $23.44 \pm 2$ \\
\hline Sangli & $6.98 \pm 0.1$ & $1.39 \pm 0.1$ & $1.94 \pm 0.0$ & $8.9 \pm 0.1$ & $21.08 \pm 0.3$ & $1.91 \pm 0.0$ & $6.83 \pm 0.2$ & $4.32 \pm 0.3$ & $5.57 \pm 0.3$ & $1.78 \pm 0.1$ & $28.42 \pm 2$ \\
\hline Jalgaon & $7.68 \pm 0.3$ & $0.15 \pm 0.1$ & $0.28 \pm 0.1$ & $14.41 \pm 0.3$ & $3.98 \pm 0.8$ & $0.36 \pm 0.0$ & $1.42 \pm 0.6$ & $1.48 \pm 0.4$ & $0.96 \pm 0.3$ & $8.19 \pm 0.9$ & $38.67 \pm 7$ \\
\hline Kolhapur & $6.53 \pm 0.0$ & $0.42 \pm 0.0$ & $0.63 \pm 0.0$ & $10 \pm 0.0$ & $3.61 \pm 0.2$ & $0.33 \pm 0.0$ & $3.87 \pm 0.3$ & $2.45 \pm 0.2$ & $11.57 \pm 0.2$ & $7.3 \pm 0.1$ & $57.47 \pm 2$ \\
\hline Osmanabad & $6.08 \pm 0.2$ & $0.43 \pm 0.2$ & $0.71 \pm 0.1$ & $5.55 \pm 0.3$ & $7.18 \pm 0.4$ & $0.65 \pm 0.1$ & $3.75 \pm 0.5$ & $3.33 \pm 0.1$ & $16.82 \pm 1$ & $13.84 \pm 0.6$ & $62 \pm 7$ \\
\hline
\end{tabular}

Note: Values are mean \pm SE of two triplicates, OC-organic carbon

Tab. 4. Jaccard similarity index of AM spore type between sugarcane growing ten surveyed districts from Maharashtra

\begin{tabular}{|c|c|c|c|c|c|}
\hline Compared District & $\begin{array}{c}\text { Jaccard } \\
\text { index }\end{array}$ & Compared District & $\begin{array}{c}\text { Jaccard } \\
\text { index }\end{array}$ & Compared District & $\begin{array}{c}\text { Jaccard } \\
\text { index }\end{array}$ \\
\hline Dhule/Aurangabad & 0.83 & Aurangabad/Kolhapur & 0.81 & Pune/Satara & 0.87 \\
\hline Dhule/Beed & 0.79 & Aurangabad/Osmanabad & 0.80 & Pune/Sangli & 0.89 \\
\hline Dhule/Ahmadnagar & 0.86 & Beed/Ahmadnagar & 0.85 & Pune/Jalgaon & 0.88 \\
\hline Dhule/Pune & 0.90 & Beed/Pune & 0.89 & Pune/Kolhapur & 0.90 \\
\hline Dhule/Satara & 0.85 & Beed/Satara & 0.84 & Pune/Osmanabad & 0.86 \\
\hline Dhule/Sangli & 0.89 & Beed/Sangli & 0.87 & Satara/Sangli & 0.92 \\
\hline Dhule/Jalgaon & 0.82 & Beed/Jalgaon & 0.80 & Satara/Jalgaon & 0.87 \\
\hline Dhule/Kolhapur & 0.86 & Beed/Kolhapur & 0.85 & Satara/Kolhapur & 0.88 \\
\hline Dhule/Osmanabad & 0.83 & Beed/Osmanabad & 0.82 & Satara/Osmanabad & 0.84 \\
\hline Aurangabad/Beed & 0.81 & Ahmadnagar/Pune & 0.87 & Sangli/Jalgaon & 0.82 \\
\hline Aurangabad/Ahmadnagar & 0.87 & Ahmadnagar/Satara & 0.84 & Sangli/Kolhapur & 0.84 \\
\hline Aurangabad/Pune & 0.89 & Ahmadnagar/Sangli & 0.91 & Sangli/Osmanabad & 0.82 \\
\hline Aurangabad/Satara & 0.83 & Ahmadnagar/Jalgaon & 0.88 & Jalgaon/Kolhapur & 0.74 \\
\hline Aurangabad/Sangli & 0.85 & Ahmadnagar/Kolhapur & 0.90 & Jalgaon/Osmanabad & 0.70 \\
\hline Aurangabad/Jalgaon & 0.78 & Ahmadnagar/Osmanabad & 0.87 & Kolhapur/Osmanabad & 0.74 \\
\hline
\end{tabular}


72

Tab. 5. Pearson correlation coefficient between spore density and AM root colonization with several soil chemical properties

\begin{tabular}{|c|c|c|c|c|c|c|c|c|c|c|c|c|c|}
\hline & $S p$ & RLC & $\mathrm{pH}$ & $\begin{array}{c}\mathrm{EC} \\
(\mathrm{d} S / \mathrm{m})\end{array}$ & $\begin{array}{l}\mathrm{OC} \\
(\%) \\
\end{array}$ & $\begin{array}{c}\mathrm{P} \\
(\mathrm{kg} / \mathrm{ac})\end{array}$ & $\begin{array}{c}\mathrm{K} \\
(\mathrm{kg} / \mathrm{ac})\end{array}$ & $\begin{array}{c}\mathrm{Na} \\
(\mathrm{meq} / 100 \mathrm{~g})\end{array}$ & $\begin{array}{c}\mathrm{Ca} \\
(\mathrm{meq} / 100 \mathrm{~g})\end{array}$ & $\begin{array}{c}\mathrm{Mg} \\
(\mathrm{meq} / 100 \mathrm{~g})\end{array}$ & $\begin{array}{c}\mathrm{Zn} \\
(\mathrm{ppm})\end{array}$ & $\begin{array}{c}\mathrm{Cu} \\
(\mathrm{ppm})\end{array}$ & $\begin{array}{c}\mathrm{Fe} \\
(\mathrm{ppm})\end{array}$ \\
\hline $\mathrm{Sp}$ & - & 0.826 & $-0.39^{\circ}$ & $-0.895^{\circ}$ & $-0.902^{\circ}$ & $-0.525^{\circ}$ & $-0.873^{\circ}$ & $-0.873^{\circ}$ & $-0.89^{\circ}$ & $-0.824^{\circ}$ & 0.672 & $0.707^{\circ}$ & $0.461^{\circ}$ \\
\hline RLC & 0.826 & - & $0.006 \mathrm{~ns}$ & -0.756 & $-0.75^{\circ}$ & $-0.438^{\circ}$ & $0-.710^{\circ}$ & $-0.709^{\circ}$ & $-0.744^{\circ}$ & $-0.715^{\circ}$ & $0.567^{\circ}$ & $0.624^{\circ}$ & $0.479^{\circ}$ \\
\hline
\end{tabular}

Note: ${ }^{*}$ correlation is significant at $\mathrm{P}<0.01$; ns-no significant, $\mathrm{Sp}$-spore density, RLC-root length colonization

tween concentrations of other cations including $\mathrm{Na}, \mathrm{Ca}$, $\mathrm{Mg}, \mathrm{K}$ and $\mathrm{EC}$ values and spore density as well as AM root colonization appeared furthest (Fig. 4).

\section{Discussion}

AM fungi are naturally associated with several plant species. Though they possess less host plant specificity, their occurrence and spore density is diverse and varies from place to place which may be related to physico-chemical properties of soil or due to variation in climatic changes etc (McGonigle and Miller, 1996; Sanders, 1990).

In the present study, variation of AM spore density and species diversity was observed in sugarcane rhizospheric soils of 41 different tehsil places belonging to 10 districts in Maharashtra, India. The lowest mean spore density observed in Dhule district was because of minimum spore count detected in Sindkheda tehsil place. It was observed that, spore density decreased significantly with increase in soil EC value and exactly the same trend of relationship was recorded in extent of AM root colonization with soil EC value. This finding was supported by the reports of several workers, where they have mentioned less spore density in saline soil (Barrow et al., 1997; Carvalho et al., 2004; Kim and Weber, 1985). The present results also support the previous findings where a negative correlation between spore density and concentrations of available $\mathrm{P}, \mathrm{Na}, \mathrm{Ca}$, Mg etc have been reported (Aliasgharzadeh et al., 2001).
The decrease in spore density with an increase in soil available phosphorus observed in the study can be attributed to the fact that, available soil phosphorus inhibits AM root colonization as well as their density (Anderson, 1992).

In the present study, soil samples of most of the districts were near neutral to slightly alkaline and genus Glomus was dominant in this soil type and it is reported that Glomus is common in neutral and slightly alkaline soils (Mukerji et al., 2002). Second dominant genus found in this study was Acaulospora and it was due to slightly acidity of soils present in some districts. Morton (1986) and Abbott and Robson (1991) have found better association of Acaulospora in acidic soil. It has already been reported that, $\mathrm{pH}$ regulates mycorrhizal status as it controls the nutrient availability from natural sources and difference in soil $\mathrm{pH}$ which actually determine the distribution of $\mathrm{AM}$ fungal species (Baylis, 1967; Moreira-Souza et al., 2003).

Considerable spore diversity was observed in sugarcane rhizospheric soil samples of various districts under this study. Among the AM species, Glomus fasciculatum, Glomus intraradices, Glomus mosseae and Glomus versiforme were found to be abundant in various locations of ten districts. Though there are variations in soil chemical properties district wise but, the frequency of these four AM species was more as compared to others. It is possible that sugarcane root acts as suitable host for the formation of mutualistic symbiosis with these AM species.

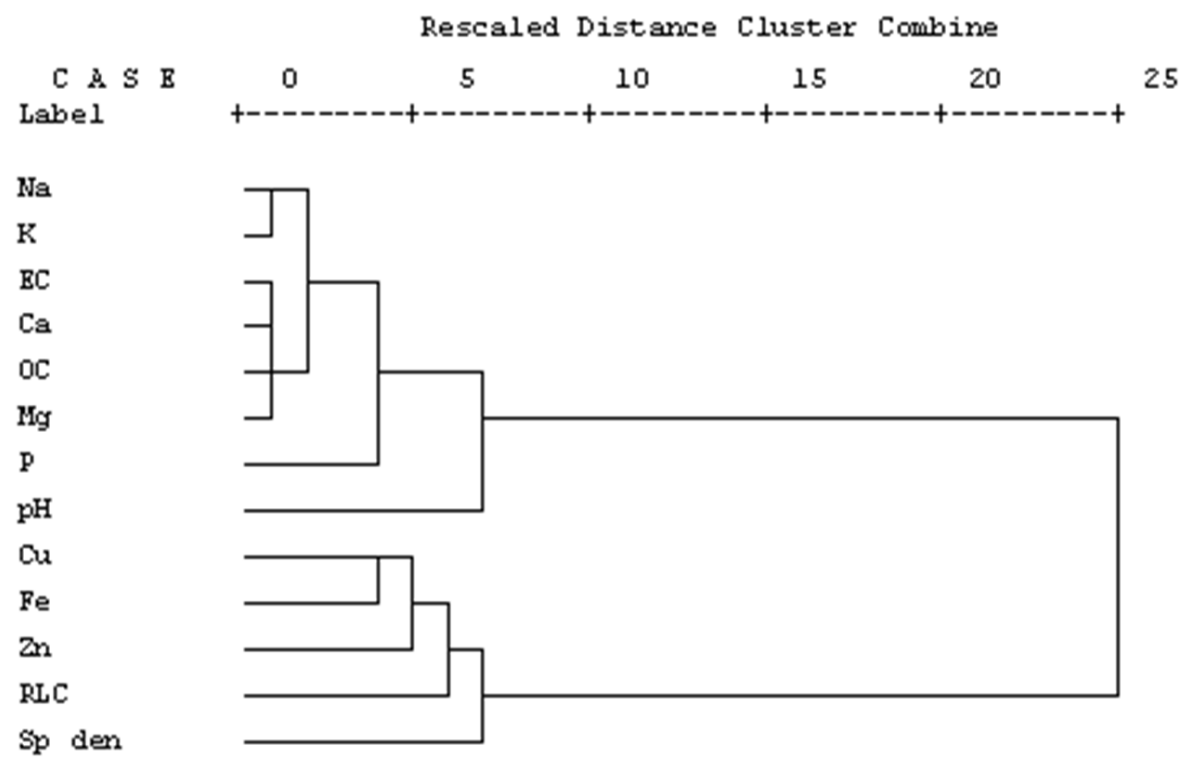

Fig. 4. Dendrogram obtained after agglomerative hierarchical cluster analysis among variables using Average Linkage.

Note: OC-organic carbon, RLC-root length colonization, Sp den-spore density 
The diversity of AM fungi at the different sites may be influenced by several environmental and biological factors (Smith and Smith, 1996). Also, several researchers have pointed out the variation in AM spore density and their sporulation in association with particular host plant is because of their dormancy, seasonal sporulation and distribution patterns of AM spore in rhizospheric soil, age of host plants etc (Bever et al., 1996; Gemma and Koske, 1988; Walker et al., 1982). It is also reported that, intraradical development of AM fungi is highly influenced by plant species, soil $\mathrm{pH}$, phosphorus contents etc (Carrenho et al., 2007). The present study indicate spore density and species diversity and their extent of root colonization in sugarcane roots is also influenced by amount of $\mathrm{Cu}, \mathrm{Fe}$ and $\mathrm{Zn}$ present in soils and this can be considered as an additional factors which supports AM spore diversity. This study would help to select appropriate AM bioinoculant for different types of soils in relation to the same host sugarcane.

\section{Conclusions}

The assessment of natural root colonization with AM fungi is essential to address the problem of nutritional management of stressed soil where crop rotation system is not followed for many years. In this study, considerable AM fungal diversity was observed under different soils with respect to the same host plant sugarcane. The variation in distribution can be correlated with $\mathrm{Cu}, \mathrm{Fe}$ and $\mathrm{Zn}$ status of the soil. But, within this diverse distribution, the species Glomus fasciculatum, Glomus intraradices, Glomus mosseae and Glomus versiforme were the most dominant and can be used individually or as a consortium as bioinoculant for improvement of sugarcane productivity. This type of study would be useful for the enhancement of sugarcane productivity in stressed soil.

\section{Acknowledgement}

Authors express thanks to Department of Biotechnology, New Delhi, India for the financial support.

\section{References}

Abbott LK, Robson AD (1991). Factors influencing the occurrence of vesicular-arbuscular mycorrhizas. Agric Ecosyst Environ 35:121-150.

Aliasgharzadeh N, Rastin NS, Towfighi H, Alizadeh A (2001). Occurrence of arbuscular mycorrhizal fungi in saline soils of the Tabriz plain of Iran in relation to some physical and chemical properties of soil. Mycorrhiza 11:119-122.

Ambrosano EJ, Azcón R, Cantarella H, Ambrosano GMV, Schammass EA, Muraoka T, Trivelin CO, Rossi F, Guirado N, Ungaro MRG, Teramoto JRS (2010). Crop rotation biomass and arbuscular mycorrhizal fungi effects on sugarcane yield. Sci Agric (Piracicaba Braz) 67:692-701.
Anderson AJ (1992). The influence of the plant root on mycorrhizal formation, p. 37-64. In: Allen MJ (Ed.). The influence of the plant root in mycorrhizal formation: an integrative plant fungal process Chapman and Hall, New York.

Asai T (1934). Über das vorkommen und die Bedeutung der Wurzelpilze in den Land pflanzen. Japan J Bot 7:107-150.

Barrow JR, Havstad KM, Mc Caslin BD (1997). Fungal root endophytes in four wing salt brush, Atriplex canescens, on arid range land of South Western USA. Arid Soil Res Rehab 11:177-185.

Baylis GTS (1967). Experiments on ecological significance of phycomycetous mycorrhizas. J New Phytol 66:231-243.

Bever JD, Morton JB, Antonovics J, Schultz PA (1996). Host dependent sporulation and species diversity of arbuscular mycorrhizal fungi in a mown grassland. J Ecol 84:71-82.

Carrenho R, Trufem SFB, Bononi VLR, Silva ES (2007). The effect of different soil properties on arbuscular mycorrhizal colonization of peanuts, sorghum and maize. Acta Bot Bras 21:723-730.

Carvalho LM, Correia PH, Martins-Loucao A (2004). Arbuscular mycorrhizal fungal propagules in a salt marsh. Mycorrhiza 14:165-170.

Danesh YR, Goltapeh EM, Alizadeh A, Varma A, Mukerjii KG (2006). Distribution and abundance of arbuscular mycorrhizal fungi from soybean rhizosphere in Iran. J Agric Tech 2:251-257.

Daniels BA, Skipper HD (1982). Methods for the recovery and quantitative estimation of propagules from soil, p. 20-45. In: Schenck NC (Ed). Methods and principles of mycorrhizal research. American Phytopathological Society, St. Paul.

Dickson S, Smith FA, Smith SE (2007). Structural differences in arbuscular mycorrhizal symbioses: more than 100 years after Gallaud, where next? Mycorrhiza 17:375-393.

Evelin H, Kapoor R, Giri B (2009). Arbuscular mycorrhizal fungi in alleviation of salt stress: a review. Ann Bot 104:12631280.

Gemma JN, Koske RE (1988). Seasonal variation in spore abundance and dormancy of Gigaspora gigantea and in mycorrhizal inoculum potential of a dune soil. Mycologia 80:211-216

Gerdemann JW, Nicolson TH (1963). Spores of mycorrhizal fungi isolated from soil by wet sieving and decanting. Trans Br Mycol Soc 46:235-244.

Giovannetti M, Mosse B (1980). An evaluation of techniques for measuring vesicular-arbuscular mycorrhizal infection in roots. New Phytol 84:489-500.

Jackson ML (1973). Soil chemical analysis. Pentice Hall of India Private Limited, New Delhi, India.

Kalra YP, Maynard DG (1991). Methods manual for forest soil and plant analysis. Region, Northern Forestry Centre, Edmonton, Alberta. Information Report NOR-X-319.

Kim CK, Weber DJ (1985). Distribution of VA mycorrhiza on 
74 halophytes on inland sea playas. Plant Soil 83:207-214.

Kumar T, Ghose M (2008). Status of arbuscular mycorrhizal fungi (AMF) in the Sundarbans of India in relation to tidal inundation and chemical properties of soil. Wetlands Ecol Manage 16:471-483.

Matamoros MA, Baird LM, Escuredo PR, Dalton DA, Minchin FR, Iturbe-Ormaetxe I, Rubio MC, Moran JF, Gordon AJ, Becana M (1999). Stress induced legume root nodule senescence: physiological, biochemical and structural alterations. Plant Physiol 121:97-111.

Mc Millen B, Juniper S, Abbott LK (1998). Inhibition of hypahl growth of a vesicular-arbuscular mycorrhizal fungus in soil containing sodium chloride limits the spread of infection from spores. Soil Biol Biochem 30:1639-1646.

McGonigle TP, Miller MN (1996). Development of fungi below ground in association with plants growing in disturbed and undisturbed soils. Soil Biol Biochem 28:263-269.

Moreira-Souza M, Trufem SFB, Gomes-da-Costa SM, Cardoso EJBN (2003). Arbuscular mycorrhizal fungi associated with Araucaria angustifolia (Bert.) O. Ktze. Mycorrhiza 13:211215.

Morton JB (1986). Three new species of Acaulospora (Endogonaceae) from high-aluminium, low $\mathrm{pH}$ soils in West Virginia. Mycologia 78:641-648.

Mukerji KG, Manoharachary C, Chamola BP (2002). Techniques in mycorrhizal studies. Kluwer Academic Publishers, Dordrecht, Boston, London.

Nasim G, Ali A, Munawar A, Bajwa R (2008). Seasonal dynamics of AM fungi in sugarcane (Saccharum officinarum L. cv. 'SPF-213') in relation to red rot disease from Punjab, Pakistan. Pak J Bot 40:2587-2600.

Phillips JM, Hayman DS (1970). Improved procedure for clearing root and staining parasitic and VA-mycorrhizal fungi for rapid assessment of infection. Trans $\mathrm{Br} \mathrm{Mycol} \mathrm{Soc}$ 55:158-161.

Powell CL (1984). Field inoculations with VA mycorrhizal fungi, p. 205-222. In: Powell CL, Bagyaraj DJ (Eds.). VA Mycorrhiza, CRC Press, Boca Raton, Florida.

Sanders IR (1990). Seasonal patterns of vesicular-arbuscular mycorrhizal occurrence in grasslands. Symbiosis 9:315-320.

Schenck NC, Perez Y (1990). Manual for the identification of VA-mycorrhizal fungi. $3^{\text {rd }}$ ed. Synergistic, Gainesville, Fla.

Sengupta A, Chaudhuri S (1990). Vesicular arbuscular mycorrhiza (VAM) in pioneer salt marsh plants of the Ganges river delta in West Bengal (India). Plant Soil 122:111-113.

Shrivastava AK, Srivastava AK, Solomon S (2011). Sustaining sugarcane productivity under depleting water resource. Curr Sci 101:748-754

Smith FA, Smith SE (1996). Mutualism and parasitism: diversity in function and structure in the "arbuscular" (VA) mycorrhizal symbiosis. Adv Bot Res 22:1-43.

Smith SE, Read DJ (1997). Mycorrhizal Symbiosis. Academic Press, London.

Smith SE, Smith FA, Jakobsen I (2004). Functional diversity in arbuscular mycorrhizal (AM) symbioses: the contribution of the mycorrhizal P uptake pathway is not correlated with mycorrhizal responses in growth and total P uptake. New Phytologist 162:511-524.

St. John TV, Koske RE (1988). Statistical treatment of Endogenous spore counts. Trans Br Mycol Soc 91: 117121.

Tressner HD, Hayes JA (1971). Sodium chloride tolerance of terrestrial fungi. Appl Microbiol 22:210-213.

Walker C, Mize CW, McNabb HS (1982). Populations of endogenaceous fungi at two locations in central Iowa. Can J Bot 60:2518-2529.

Walkley A, Black IA (1934). An examination of the Degtjareff method for determining soil organic matter and proposed modification of the chromic acid titration method. Soil Science 37:29-38.

Zar JH (1984). Biostatistical Analysis. Prentice-Hall, Inc. Englewood Cliffs, New Jersey, USA. 